\title{
Philip L. Gildenberg, MD, PhD, 1935-2020
}

\author{
David W. Roberts \\ Department of Surgery, Dartmouth-Hitchcock Medical Center, Lebanon, NH, USA
}

Philip L. Gildenberg, MD PhD, Editor of Stereotactic and Functional Neurosurgery from 1975 to 2002, died on January 15 , at the age of 84 . He was a giant, a leader and a friend of the stereotactic community for more than half a century.

Dr. Gildenberg was born on March 15, 1935, in Hazelton, Pennsylvania, and was educated at the University of Pennsylvania (A.B., Zoology, with Honors) and Temple University Medical School (MD, MA in Experimental Neurology, and $\mathrm{PhD}$ in Neurophysiology). His doctoral thesis, entitled "Functional connections between cortex and vestibular nuclei in cat and monkey" was completed during a Fellowship at the Max Planck Institut für Hirnforschung in Frankfurt, Germany. He completed his neurosurgical residency at Temple, and following two years as a Medical Research Officer at the U.S. Naval Medical Research Institute in Bethesda, Maryland, took his first academic position, with responsibility for the research program, at the Cleveland Clinic. In 1972, he started the Neurosurgery program at the University of Arizona in Tucson, and three years later the new program at the University of Texas Medical School in Houston. He spent the remainder of his professional career in Houston, with appointments at the University of Texas Medical School and at Baylor Medical College. He discontinued clinical practice in 2001 but remained engaged in the activities of stereotaxy as well as in the development of medical technology, founding five companies, three in robotics.

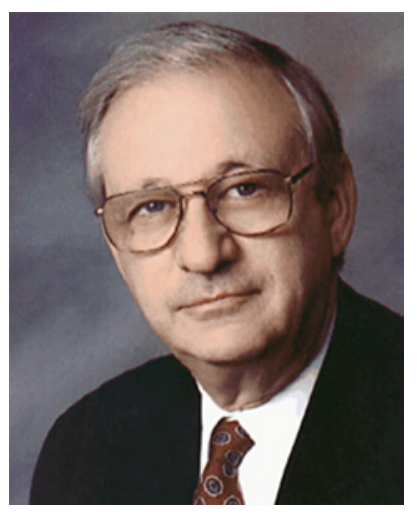

Philip L. Gildenberg, $M D, P h D$

It was in his earliest days as a medical student at Temple that he came under the influence and tutelage of his mentor and graduate student advisor, Ernst A. Spiegel. He worked in Professor Spiegel's laboratory, assisted him with his journal Confinia Neurologica, participated in surgeries of his neurosurgical colleague, Henry T. Wycis, was introduced to neuroscientists and neurosurgeons from around the world who visited Spiegel, and attended the earliest gatherings of the nascent stereotactic field.

Having assisted Spiegel with his journal as a student, resident, and graduate student, Dr. Gildenberg assumed the official role of Associate Editor of Confinia Neurologica in 1968. Seven years later, he succeeded his mentor as Editor, and recognizing the increasingly clinical orientation of the journal, changed its name to Applied Neuro- karger@karger.com

www.karger.com/sfn

(c) 2020 S. Karger AG, Basel

Karger"
David W. Roberts

Department of Surgery, Dartmouth-Hitchcock Medical Center

One Medical Center Drive

Lebanon, NH 03756-0001 (USA)

david.w.roberts@dartmouth.edu 
physiology (it would become Stereotactic and Functional Neurosurgery in 1989). For most of the next three decades, he personified the journal. For many of us, our first introduction to Dr. Gildenberg and his wife, Pat Franklin, was at the beginning of a meeting of the American or World Society for Stereotactic and Functional Neurosurgery, where they would sit at a table just outside the auditorium, collecting from each speaker a manuscript of the talk about to be given. While Associate Editor Franklin logged in the paper, checked figures, and totaled page counts, Dr. Gildenberg would greet old and new friends and inevitably share a highly relevant anecdote about a key individual related to the topic or an earlier reference that had been overlooked or unknown by the author. With each passing participant, the process was repeated. These manuscripts would be published by the journal, sometimes as an entire year's two volumes, with the Proceedings serving as the archive of the specialty's first reports and pilot studies. That table was quintessential Dr. Gildenberg in so many ways: his central role at any stereotactic meeting for as long as anyone remembered, his total devotion to the journal, his personal relationship with the entire stereotactic community, his deep and erudite command of the field, and his thoughtful, soft-spoken, kind, and generous spirit. Dr. Gildenberg advocated for every author, often personally re-writing entire manuscripts from non-English-speaking countries.

Stereotactic neurosurgery and the journal grew as one, and just as he picked up the editorial mantle from Spiegel, he quietly took on increasing responsibility for meetings of the specialty. He was asked to be Secretary-Treasurer of the WSSFN in 1976, serving as the organizational glue for the activities of a small, widely dispersed, and (sometimes) like-minded enthusiasts. After 17 years in that role, he transitioned to the Presidency. He served in the same Secretary-Treasurer capacity for the ASSFN from 1972 to 1997 except for four interposed years as President, a role he reprised in 1997. In both societies, the more essential work lay in the less titled position. After retiring from clinical practice, he remained a presence at all meetings as board member, historian or elder statesman, sitting to the side and called upon to educate and advise the next generation.

With his friend, Ronald Tasker, he co-edited the encyclopedic text of the discipline, Textbook of Stereotactic and Functional Neurosurgery (1998), a second edition of which he edited with Andres Lozano in 2009. His attentive erudition informed all meetings large and small. The prestigious Gildenberg Award, presented to a resident or fellow for the best research in stereotactic and functional neurosurgery, has been given annually since 2004 .

Dr. Gildenberg and his wife, Pat Franklin, were an inseparable team, and she died four days after her husband. They will be forever missed. Dr. Gildenberg was a guiding presence in stereotaxy all of his professional life, and his legacy - through the World and American Societies, through the pursuit of excellence in investigative and clinical stereotactic practice, and through our journal, Stereotactic and Functional Neurosurgery - will be with us always. 